\title{
EDITORIAL
}

\section{STEM in Early Childhood Education}

\author{
Hanno van Keulen ${ }^{1 *}$ \\ ${ }^{1}$ Windesheim University of Applied Sciences, NETHERLANDS \\ *Corresponding Author: h.van.keulen@windesheimflevoland.nl \\ Citation: van Keulen, H. (2018). STEM in Early Childhood Education. European Journal of STEM Education, \\ 3(3), 06. https://doi.org/10.20897/ejsteme/3866
}

Published: September 6, 2018

This special issue of the European Journal of STEM Education is dedicated to STEM in early childhood education. Early childhood education with respect to STEM already starts in the womb, when the not-yet-born baby accustoms itself to the material world surrounding it (Smith and Gasser, 2005). Certain sounds become familiar and newborns can already discriminate their mother tongue from other languages. After birth, the force of gravity imposes itself on the child, forcing it down. This is the start of a yearlong struggle to rise, which becomes the source of many metaphors we all use to make sense of our lives. When things do not go our way, we feel down and depressed. When we succeed, we lift our hearts and enjoy high spirits. Consequently, teaching children the meaning of 'up' and 'down' is much easier than teaching them 'left' and 'right', as any parent and Kindergarten teacher will know. 'Up' and 'down' are extremely meaningful and important to the child, whereas 'left' and 'right' are often quite arbitrary. Since we are subjected to gravity, we need flat feet and strong legs to cope with that force. We would notice it immediately when someone stands on its head and hands. But do you know which hand your colleague uses to pick up that cup of coffee?

Children perceive and act before they can speak or think consciously. Experiences in and with the material world are the starting point of cognitive development. STEM in early childhood education is not explaining children the laws of gravity; it is guiding them to and through experiences in which gravity plays a decisive role. Or any other concept that is important to children's lives. Children are not yet interested in correct reproductions of true statements about the world. They first of all want to know what the things in the world afford them to do (Gibson and Pick, 2000). Can you eat it? Is it safe? The motor system will children help to act, and the sensory system will help them to correlate objects and phenomena in the world to their experiences. STEM in early childhood education is about rich material environments that children can explore. It is also about helping them with conceptual development, by drawing their attention to salient features and by suggesting words for 'this' and 'that'. Conceptual development starts with experiences that impose themselves upon the child and crave for attention and interpretation. Some things make sounds, some things flow, some things can be put in other things. The development of verbal language skills and vocabulary cannot do without this process, and the development of scientific concepts cannot do without the metaphorical use of words like 'up', 'in' or 'current' (Lakoff and Johnson, 1980; Browne, 2003).

Words do not just come from personal, individual experience. They are suggested to the child from the social community in which it grows up. High quality interaction with adults, or older children, is as important for understanding the world and for healthy development as having the rich material experiences themselves. Learning about the material world is learning to play, is learning a language, is learning social skills, is learning to communicate (Van Oers, 2013; Vygotsky and Luria, 1994).

Learning about the material world of course is also learning about STEM. STEM is about questions that can be explored scientifically; or about technological problems that can be solved through engineering and design. These questions and problems will take on sophisticated, often mathematical expressions in adult and professional life. They will build on previous experiences and conceptualizations. But when you unwrap all these layers of 
conceptions and technology that uses other technology (Arthur, 2009), you will see that the laser pointer you use in your lectures is just your finger, but improved. Your cell phone is just your voice, but improved, so that it carries your voice over distance. Technology is an embodied answer to our embodied problems and that is why we have, or should have, an intuitive understanding of technology.

Alas, many people seem to become alienated from the material and technological world when they grow up (ASPIRES, 2013). In many countries, too few young people aspire for a career in science or engineering. Something goes wrong and schools seem to play a part in this. Instead of stimulating children to plunge headlong in the material world and start making sense of it, many teachers fear the openness and lack the pedagogical repertoire to guide children from experience to insight. Explorations quickly become messy and unpredictable, and children can ask questions that are difficult to answer. So instead of relying on the power of children's direct experiences of phenomena, too many teachers rely on mediators like textbooks and paper and pencil exercises or refrain from teaching STEM at all. It is okay when children play in the sandbox in their own time, but this is not 'real learning'. And yes, when they are sixteen, children may know that water is $\mathrm{H}_{2} \mathrm{O}$, that a whale is a mammal and jeans are made of cotton, but many will have lost contact with the processes that lead to this knowledge and to these products, and they do not know both the joy and the frustration that comes with investigating, designing, making, modeling, testing, improving and explaining.

So, it is vital to start teaching STEM at an early age and teach it well. Good teaching should be evidence based, or at least evidence informed. That is why research is important. And research on STEM in early childhood education can be quite divers, as is exemplified by the contributions to this special issue.

In the first contribution, John, Sibuma, Wunnava, Dubosarsky and Anggoro propose a problem-based curriculum for three- to five-year old children, with an explicit focus on engineering problems. They find that this affects engagement of the children but also the self-efficacy of the teachers.

Bers writes about ScratchJr, a tool with which children who cannot yet read or write can create programs. Certainly digital technology is of great relevance in the present and future life of young children, and it is important to give coding and computational thinking its proper place in educational settings.

Strawhacker and Bers focus on another big hype, the Maker Movement. They investigated a Kindergarten classroom that contributes to the children's technological development and found that Makerspace activities definitely have potential but that teachers' interaction with children matters too.

Engineering design problems are introduced in Kindergarten by Tank, Rynearson and Moore to investigate whether young children can engage in the stages of engineering design processes and learn to use engineering language.

Malone, Tiarani, Irving, Kajfer, Lin, Giasi and Edmiston bring engineering design challenges to Kindergarten, incorporated in drama, dance, visual arts and physical education. They investigated the effects on the understanding of what engineers do and of technology and found significant increases.

Ralph and Petrina focus on social learning with mobile devices, gathering data by using cameras worn by participants. They show that it is at least possible (if not guaranteed) to induce more prosocial sharing behaviors in children aged 3-4 when interacting with mobile devices.

Scientific reasoning is considered by many to be difficult. Van der Graaf, Segers and Verboeven investigate the experimentation ability of Kindergarten children with learning problems.

Many children are anxious about mathematics. Fumer investigates the mediating role of using children's books and children's literature in math lessons on developing mathematically confident young people, feeling that as children are less anxious, their performance may improve.

Stylianidou and co-workers, among them the late Anna Craft, reflect on the results of the 2011-2014 Creative Little Scientists project and provide recommendations to foster inquiry and creativity in early years STEM education.

Sumpter and Hedefalk analyze the strategies ('epistomological moves') teachers use to promote mathematical reasoning in preschool. They find that teachers most often instruct, confirm or conclude, but that they hardly use generative strategies that help children to produce arguments themselves and thus do not stimulate children to learn creative mathematical reasoning.

STEM learning does not only take place at schools or in day care settings. For young children, the family is the most important learning environment. Sheehan, Hightower, Lauricella and Wartella investigate whether parents' attitudes on STEM and their acquaintance with STEM careers predict their children's science and math skills, with interesting findings.

DeJarnette wants to add the A of Arts to STEM, because both develop curiosity and creativity. She investigates the effects of a professional development program on preschool teachers' self-efficacy and disposition to implement STEM.

Without the effort of the guest editors, Hannelie du Preez from Pretoria University in South Africa, Fani Stylianidou from Ellinogermaniki Agogi in Greece and Estelle Blanchet from Bordeaux University in France and 
also coordinator of the Special Interest Group of the European Science Education Research Association (ESERA), creating this special issue would not have been possible. Without many reviewers devoting precious time to carefully providing feedback to the authors, we would not have reached this high quality. Thank you all!

So, enjoy reading and apply the insights to your own research and/or your educational practice!

\section{REFERENCES}

Arthur, W. B. (2009). The nature of technology - What it is and how it evolves. New York: Free Press.

ASPIRES. (2013). Young people's science and career aspirations, age 10 -14. London: King's College London.

Browne, T. L. (2003). Making truth. Metaphor in science. Urbana: The University of Illinois Press.

Gibson, E. J. and Pick, A. D. (2000). An ecological approach to perceptual learning and development. New York: Oxford University Press.

Lakoff, G. and Johnson, M. (1980). Metaphors we live by. Chicago: University of Chicago Press.

Smith, L. and Gasser, M. (2005). The Development of Embodied Cognition: Six Lessons from Babies. Artificial Life, 11, 13-29. https://doi.org/10.1162/1064546053278973

Van Oers, B. (2013). Is it play? Towards a reconceptualisation of role play from an activity theory perspective. European Early Childhood Education Research Journal, 21(2), 185-198. https://doi.org/10.1080/1350293X.2013.789199

Vygotsky, L. S. and Luria, A. R. (1994). Tool and symbol in child development. In R. van der Veer and J. Valsiner (Eds.), The Vygotsky Reader (pp. 99-107). Cambridge (MA): Blackwell. 